\title{
SELF-REFLECTION AS A TOOL OF PROFESSIONAL IDENTITY FORMATION OF FUTURE PEDAGOGUES
}

\author{
(C) LIAUDANSKE, VILMA \\ Dr., Department of Pedagogy, Arts and Social Work, \\ Marijampole University of Applied Sciences (Marijampole, Lithuania) \\ E-mail: vilma.liaudanske@mkolegija.lt \\ ORCID iD: https://orcid.org/0000-0002-4079-7232 \\ Маріямпольський університет прикладних наук, вул. П. Арміно 92, LT-68125, Маряямполе, Литва \\ Marijampole University of Applied Sciences, str. P. Armino 92, LT-68125, Marijampole, Lithuania
}

\begin{abstract}
Abstarct
The relevance of this study. The method of self-reflection is an important factor in practical activity of a pedagogue, seeking to increase his work efficiency, strengthen relationship between ideal and real phenomena. Self-reflection also helps to feel satisfaction in one's work. Self-reflection facilitates cooperation between a pedagogue and a client or colleagues. Leliugiene treats self-reflection as objective analysis of professional social - pedagogical activity. She states, that the origin of reflection process is one's early relationships with an important person, who should create such environment for a child, in which he can understand his and others' psychological states and form his reflective function. Lukosiuniene has found out that reflection is useful for learning, work and personal life of specialists. The main problem. A pedagogue has to analyze and assess his professional activity constantly and seek to improve it. Applying various methods a pedagogue can assess his activity, whereas self-reflection is one of such methods. Thus the author of this article tries to answer the problematic question - how future pedagogues apply the method of self-reflection into the process of practical learning. Object of research: the aspects of self-reflection application, forming professional identity of future pedagogues. The goal - analyse the aspects of self-reflection application in the process of practical learning (as one of the stage of professional identity formation) of future pedagogues. Research methods: analysis of research literature and documents, analysis of students' diaries of practical learning and their self-reflection of practices, content analysis. The article consists of three parts. The author discusses importance self-reflection in the activity of pedagogues in the first part. The role of self-reflection application in the process of future pedagogues is presented in the second part. And the main results of the empirical research are presented in the third part of the article.
\end{abstract}

Key words: self-reflection, profesional identity, social pedagogy, social pedagogue, practical learning

\section{Statement of the problem}

One of the functions of pedagogy and its scientific branch social pedagogy is formation of a personality and support for the individual, adapting to his social environment, which is rapidly changing. And in that context the person should found his ego through his abilities and skills [8; 11].

Pedagogy also carries out the functions of the individual's soul development, social support, education of a person, who is able to think critically and is self-confident. According to the conclusion of Leliugiene [8], living in the modern changing society, a social pedagogue lays on all his expectations on a young person, who is willing and able to use all opportunities to become a fully-formed personality.

Thus a social pedagogue applies four forms of professional activity in his work: he works with families, groups, with delinquent children and teenagers, and also with individual clients [8]. The application of psychological methods of activity, working with children and teenagers, having behavioural and educational problems, gives considerable possibilities and ways to help developing personality to adopt to one's social environment and conform the strict requirements of modern society [18]. The method of self-reflection is one of the methods, which enable a social pedagogue to provide effective socio-educational support.

Leliugiene [8] treats self-reflection as objective analysis of professional social - pedagogical activity. She states, that the origin of reflection process is one's early relationships with an important person, who should create such environment for a child, in which he can understand his and others' psychological states and form his reflective function. Lukošiuniene [14] has found out that reflection is useful for learning, work and personal life of specialists.

The research problem analysed in that article. A pedagogue has to analyse and assess his activity constantly and seek for its improvement. Applying different methods, a pedagogue can assess his activity. Self-reflection is a proper method to do that. 
Thus it is very important for the future pedagogues to perceive the technology of self-reflection application. The author of the article seeks to find an answer to the question - how the method of self-reflection is applied in the process of studies of pedagogues.

The research object - the aspects of self-reflection application, forming professional identity of future pedagogues.

The goal of the article - analyse the aspects of self-reflection application in the process of practical learning (as one of the stage of professional identity formation) of future pedagogues.

The objectives are the following:

1. Discuss the conception of self-reflection and its importance in the activity of a pedagogue.

2. Review the aspects of self-reflection application in the process of studies of future pedagogues.

3. Find out what issues are important for students of social pedagogy in the self-reflection of their practical learning.

The article is prepared using the following research methods: analysis of research literature and documents, analysis of students' diaries of practical learning and their self-reflection of practices, content analysis.

\section{Importance of self-reflection in activity of a pedagogue}

Self-reflection-conscious, dynamic contemplation and analysing of experience, which helps to understand one's ego and to perceive one's experience [5].

According to Leliugiene [8], self-reflection is «self-analysis - objectively evaluated analysis of professional social-pedagogical activity». Reflection (Latin «reflexion» - turning, reconstruction) is defined as way of thinking, which helps to understand and critically analyse one's assumptions and forms of cognition [17]. The conception of reflection is derived from the ancient times; it was important in philosophy and was understood as thinking of the individual about the issues, which occurs in his consciousness [18].

The basis of the conception of reflection is the provisions of J. Dewey's reflexive thinking [quoted 14], which essence is one's responsibility for future consequences, arising from a present action. Lukosuniene [14] defines reflexive thinking as cautious contemplation of one's attitudes. It is as a form of cognition, which encourages investigating facts, denying or approving of results. J. Dewey [quoted 14] identifies reflection with thinking, through which we can see relationships between efforts and outcomes.
Self-reflection is connected with abilities of selfobservation and willingness to know more about one's life goals, self-essence and true «self». Selfreflection is necessary for one's successful cognitive and social development. Therefore every person in adolescence experiences the period of questioning, investigations and self-reflection, which builds foundations for self-identity [12].

Reflecting a person has opportunity to contemplate, review all his life -i. e. what he does, where he is, and to decide, where he wants to go indeed [9].

Jovaisa [6] connects reflection with the method of one's activity or behaviour assessment, assessing results of activity, identifying the necessity of activity improvement. Kavaliauskiene [10] states, that reflection is essential characteristic and principle of person's consciousness, which explains content of social phenomena; and it reveals itself as behaviour, relationships and activity of that person. The author also states that reflection - the turning of thinking from the observation of external world to the observation of «self».

Analysing the process of self-reflection, it is possible to distinguish two forms of analysing and reflecting: the first, when a person contemplates his behaviour, values, experience; and the second, when he contemplates the actions of others (Fig. 1) [3].

Why is importance of self-reflection emphasized in the process of learning? D. Boud et al [quoted 13] connect (self)reflection with learning and state that personal experience is valuable in the process of learning as an object of self-reflection, because it is connected with a person's intellectual and affective activity, when he, contemplating his experience, discovers new perception and assessment [13].

According to the opinion of J.A. Moon [quoted 13], self-reflection is the necessary precondition for successful learning, because it is a form intellectual activity, which helps to develop abilities of analysing, when knowledge and experience are analysed and deeper essences and understanding are discovered.

Self-reflection is needful condition for successful activity of a pedagogue, because only that pedagogue, who has well developed skills of self-reflection, can understand others (their motivation, educational problems and needs) and understand himself, as a specialist, who helps others to learn and seeks to improve his activity.

A pedagogue as a professional specialist use selfreflection for the following goals:

- Develop his work with children and families skills; 


\section{Self reflecting}

- Evaluate one's skills and abilities.

- Defined goals, their implementation monitoring, self-motivation.

- Investigate one's beliefs and compare them with beliefs of others.

- Perception of self as a part of bigger community.

- Self-report about one's actions and their influence on others.

- Respect one's rights and dignity of others.

- Assessment and evaluation of new ideas.

Fig. 1 Directions of reflecting

\section{Reflecting about others}

- Respect beliefs of others.

- Protect security of others.

- Transform one's abilities and beliefs, considering other individuals and groups.

- Apply the proper techniques of conflicts' solving.

- Contemplate differences between oneself and others.

- Perceived importance of humor and empathy in the process of interpersonal interactions.

- Meet the needs of a community; support a community.

Source: [3]

- Develop his communication skills and team work skills;

- Understand how his experience and attitudes influence his work [15].

The basis of the process of professional development is reflection of a subject's activity, which is defined as self-reflection - i. e. objectively assessed analysis of professional pedagogical activity [8].

The analysis of research literature showed that self-reflection could be defined as self-assessment and self-evaluation of one's activity and personality. Self-reflection - analysis and contemplation of one's professional activity, positive and negative emotions, experience, critical assessment of one's and others' activity. Self-reflection is the necessary presumption for successful activity of a pedagogue. Thus the aspects of self-reflection application in the process of future pedagogues' studies are discussed in the other part of the article.

Role of self-reflection application in the process of studies of future pedagogues

The general professional competences of a teacher are presented in the Description of Teacher Profession Competence [19], approved by the Government of Lithuanian Republic; and the competence of reflection and learning to learn is emphasized here. This competence consists of the abilities: organize one's learning individually and in a group; evaluate the advantages and disadvantages of professional practice, identifying perspectives of professional development; renew constantly one's knowledge and develop skills.

According to Puzyrejus [quoted 1], if a person plans to do some activity purposefully, at first he must to make decision on his inner values, thus it is the most important to form professional thinking and ability to reflect, preparing a specialist.

Bubnys [2] states that one of the goals of higher education is development of students' abilities of reflecting and learning to learn, continually analysing their experience. He accentuates the expediency of possibilities to create for reflecting, there individual experience, thinking, emotions, behaviour and values are the elements of reflecting. Bubnys [2] defines reflecting as competence, which is the important goal of lecturers and future specialists preparation, during which it is possible to achieve efficiency of teaching and learning. Philosophy of activity reflecting and learning, based on reflection, starts form everyday experience in a higher school. Reflection helps to feel experience and gives a sense to it, and that can support learning and personal and professional effectiveness.

Skills of reflecting are important to all professions, which are attributed to the field of social professions. According to Swindell and Watson [16], students, scientists and practioners of social work have to perceive their code of ethics, moral boundaries, attitudes and value system, in order to work effectively in diverse society. 
Students are supposed to develop their abilities to reflect their value system, models of practical activity, theoretical knowledge [16]. Reflection in professional activity helps to form self-cognition and self-understanding of a specialist, strengthens professional development. Self-cognition makes wider specialist's knowledge about his physical, emotional and spiritual state. Their interpretation can change professional consciousness, turn to search for new activity sense [10].

The important questions, what methods help students to develop their skills of reflecting? Fidelindo and Timothy [5] note that conducting of an activity journal or a diary, letters writing, personal blogs are appropriate forms of narrative reflecting.

Records, in which students describe their contemplations about various concepts or phenomena, learning process, interactions with other students and teachers, help students to review their learning process and / or behaviour, recognize their abilities, create own learning strategies [13].

Conducting of a diary of reflective activity is the emphasized necessity. Conducting of a diary encourages pedagogues to plan, do their job and describe it after contemplations. Geleziniene [4] discusses Buehl ideas, who diary writing treats as effective strategy, which encourages students to think what and how they are learning, while pedagogues can get direct feedback, using that method. Besides, conducting of reflecting diary develops cognitive abilities of learners [13].

Ivanauskiene, Liobikiene [7] noticed that there is paid very little attention to student's self-cognition, self-analysis during their studies, thus teachers of a higher school aim to prepare a student for the process of permanent self-reflection in the initial courses of social work studies.

There is applied the method of reflections writing as a primary method on purpose to help students to know themselves. Ivanauskiene, Liobikiene [7] have presented the following goals of reflections:

- Help a student to give a look at himself in the process of learning;

- Learn to recognize his emotions and express them;

- Develop social pedagogue's skills of recording;

- Strengthen relationships between a student and a teacher.

The effective strategies of reflecting, which students should learn, are presented in the article Self-Reflection and Shared Reflection as Professional Tools [15]:
- Observe and remember what is going on - it is useful for students to remember and reflect their observations. Recording of reflections in a confidential notebook is appropriate for that purpose.

- Contemplate, how your experience influences you and your work - it is important to understand own personal reaction (how a certain work situation makes you feel) and professional actions (how you decide to act professionally in words or in actions) in that case.

- Think from the perspective of other persons contemplate the experience of others, the influence of their cultural environment on their actions and reactions in certain circumstances. Understanding of others helps understand better oneself.

- Identify stressors - identification of stressors helps to perceive professional risk and self.

As Ivanauskiene and Liobikiene [7] state, comments and remarks of a teacher are very important, thus students are asked to write down what they are feeling, thinking. During the process more spontaneity, self-esteem are noticed in the reflections of students. Reflection turns to support process and cooperation between a student and a teacher in some cases. Ivanauskiene and Liobikiene [7] suggest that a teacher should be empathic, sensitive, sincere, and objective. He should listen to a student, thank him for reliance and frankness; these characteristics are necessary for a teacher, who applies method of reflection in his work.

Application of self-reflection helps a pedagogue to know better himself, identify positive and negative aspects of his activity, and that is opportunity to learn from one's experience and from others. Developing skills of self-reflection, students develop their abilities of critical and analytical thinking, know their value system, and develop skills of empathy. Writing of reflective journal or diary is an effective method of learning based on self-reflection.

The research of self-reflection application by the future pedagogues in the process of their practical learning

Methodology of the research. The author analyses how the students of Social pedagogy apply the method of self-reflection in the process of their practical learning.

The research has been implemented in $\mathrm{X}$ higher school of Lithuania (university of applied sciences) in 2015-2019. This higher school is a college type institution, situated in the middle of Lithuania. Graduates of that study program obtain the degree of professional bachelor, and the qualification of a social pedagogue. 
Great attention is paid for students' practical teaching in that programme, about 20 percent of studies are appointed to practices of professional activity. Students can execute their practice in institutions, providing educational or social services, in which social pedagogues are employed. The place of practice can be an institution of pre-school education, comprehensive school, care institutions, day centres for children and other institutions.

The base of the empirical research - qualitative analysis of practical learning reports of future pedagogues. Two parts of practices reports were selected for the analysis - the content of practices diaries and self-evaluation of practices. The analysis of these practices reports enabled the author to evaluate, what future pedagogues describe, using the method of self-reflection.

The respondents -6 the Ist and IIIrd cources Social pedagogy students from the X higher school of Lithuania, who have executed the Ist practice of professional activity (socioeducational work) (3 respondents) and the Final practice of professional activity (socioeducational work) (3 respondents). The respondents were selected using the method of target selection. That means that the researcher from the lists of I-\$5II courses students selected 6 respondents.

The quotes (thoughts) of the respondents from their practices diaries and self-assessment were selected and analysed, applying the method of content analysis. The respondents describe events of practices, their own activity and actions of other persons, present contemplations about their behaviour and emotions in that quotes.

The author adapted Geleziniene [4] the system of categorization of teachers, who educate children with special needs, experience for the categorization of practices diaries and self-assessment. The system of categorization is presented in the figure 2 .

Seeking to ensure confidentiality of the respondents, the researcher has given codes to them: respondent $\mathrm{A}$, respondent $\mathrm{B}$, respondent $\mathrm{C}$ (students, who have executed the Ist practice of professional activity), respondent $\mathrm{D}$, respondent $\mathrm{E}$, and respondent $F$ (students, who have executed the Final practice of professional activity).

Analysis of practical learning diaries of future pedagogues. Students get acknowledged with the activity of social pedagogues, analyzes their work programmes, assist in some activities, working with children. The respondents write about their feelings during the first day of practice, they discuss how staff of schools and pupils meet them (Table 1).

The respondents feel themselves embarrassingly during the first day of the practice, but they have noticed that the staff of a school and pupils have met them warm and welcome. Respondent $\mathrm{A}$ has paid the greatest attention to various activities of her and her mentor. The respondent emphasized the cosy environment of a practices place as the important aspect of her positive emotional state. She has also emphasized the benevolent help from her mentor's side.

Respondent $\mathrm{B}$ discusses how he has done tasks of the practice and describes his (positive and negative) emotions and emotions of other persons - the mentor, teacher, pupils. Warm and friendly welcome of pupils and their communication have made the greatest impression on him: "The pupils with the smiles on their faces waited for various tasks of activity, and did them very willingly.»

Respondent $\mathrm{C}$ describes her contemplations, how to do practice tasks more effectively, seeking to be

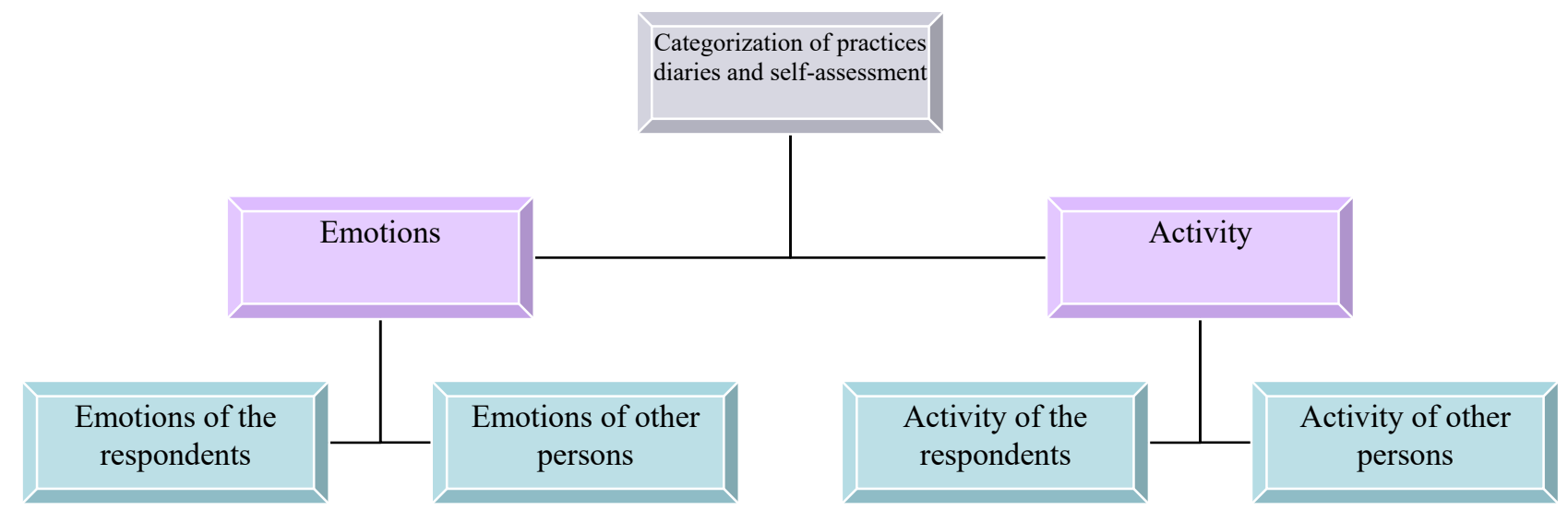

Fig. 2. The categorization of practices diaries and self assessment content

Resource: [4] 
Table 1

Categorization of diaries of the Ist professional activity practice (N)

\begin{tabular}{|c|c|c|l|c|}
\hline Categories & $\begin{array}{c}\text { Sub- } \\
\text { categories }\end{array}$ & $\begin{array}{c}\text { Theme of } \\
\text { subcategory }\end{array}$ & \multicolumn{1}{|c|}{ Statements } & $\begin{array}{c}\text { Number of } \\
\text { statements }\end{array}$ \\
\hline \multirow{5}{*}{ Emotions } & $\begin{array}{l}\text { Feelings of } \\
\text { respondents }\end{array}$ & Positive & $\begin{array}{l}\text { Comfortableness of cabinets and all work environment. } \\
\text { Warm meeting form a side of a social pedagogue. } \\
\text { Warm meeting from a side of other staff. } \\
\text { Close communication with pupils, their friendliness. }\end{array}$ & 4 \\
\cline { 2 - 5 } & $\begin{array}{l}\text { Feelings } \\
\text { of other } \\
\text { persons }\end{array}$ & Negative & $\begin{array}{l}\text { Big number of irresponsible and undisciplined pupils in the school. } \\
\text { Demand of young social pedagogues. } \\
\text { Demand of other young specialists. }\end{array}$ & 3 \\
\hline \multirow{4}{*}{ Activity } & $\begin{array}{l}\text { Warm pupils cooperation with students-trainees. } \\
\text { Great support of a social pedagogue. } \\
\text { Suggestions and examples from a social pedagogue. } \\
\text { Created opportunities to execute practice. }\end{array}$ & 4 \\
\cline { 2 - 5 } & Activity of respondents & $\begin{array}{l}\text { Discussion of activity organization. } \\
\text { Student-trainee helps his mentor. } \\
\text { Preparation of activity programme. }\end{array}$ & 3 \\
\cline { 2 - 5 } & Activity of other persons & $\begin{array}{l}\text { Discussion of activity organization with a student. } \\
\text { Mentor gets assistance from a student-trainee. } \\
\text { Help to a student preparing his activity programme. }\end{array}$ & 3 \\
\hline
\end{tabular}

useful for pupils and a mentor. Animation activity (pupils' drawings contest) with pupils has evoked positive emotions of the respondent. She has also emphasized that a mentor has liked that activity.

The respondents write very little about feelings of other persons in their diaries. The most important impression of the respondents described in their diaries - goodwill, friendliness of mentors and support from mentors' side. During the last day the practice the respondents have discussed their impressions about the practice with mentors, have evaluated their activity. Respondent $\mathrm{C}$ has noticed that "profession of a social pedagogue is difficult, but interesting» (Table 2).

Summarising the ideas of the respondents, it is possible to state that writing the diaries of the Ist professional activity practice, the respondents have paid more attention to the description of their activity, how they have managed to do practice tasks,

\section{Categorization of diaries of the Final professional activity practice (N)}

\begin{tabular}{|c|c|c|c|c|}
\hline Categories & $\begin{array}{c}\text { Sub- } \\
\text { categories }\end{array}$ & \begin{tabular}{|c|} 
Theme of \\
subcategory
\end{tabular} & Statements & $\begin{array}{l}\text { Number of } \\
\text { statements }\end{array}$ \\
\hline \multirow{3}{*}{ Emotions } & \multirow[t]{2}{*}{$\begin{array}{l}\text { Emotions } \\
\text { of the } \\
\text { respondents }\end{array}$} & Positive & $\begin{array}{l}\text { The respondent haven't faced difficulties communicating with } \\
\text { pupils. } \\
\text { They are happy that mentors helped them, when they have met } \\
\text { problems. } \\
\text { They have noticed they emotional attachment to pupils. } \\
\text { The respondent feels happy that she can help a pupil. }\end{array}$ & 4 \\
\hline & & Negative & $\begin{array}{l}\text { Worries about lack of time to prepare to pupils employment. } \\
\text { Difficulties working independently. }\end{array}$ & 2 \\
\hline & $\begin{array}{l}\text { Emotions } \\
\text { of other } \\
\text { persons }\end{array}$ & Positive & $\begin{array}{l}\text { Mentors are surprised at students' creativity. } \\
\text { Pupils are happy having possibility to develop their social skills } \\
\text { under supervision of students-trainees. }\end{array}$ & 2 \\
\hline \multirow[t]{2}{*}{ Activity } & \multicolumn{2}{|c|}{$\begin{array}{l}\text { Activity } \\
\text { of the respondents }\end{array}$} & $\begin{array}{l}\text { Meeting with the pupils, which students already know from the } \\
\text { previous practice. } \\
\text { The respondents selected one or more pupils for the practice task } \\
\text { (individual socioeducational work). } \\
\text { Provision of support to a pupil - preparation of support plan and } \\
\text { its implementation. } \\
\text { The respondents give lessons of social skills development. }\end{array}$ & 3 \\
\hline & \multicolumn{2}{|c|}{$\begin{array}{c}\text { Activity } \\
\text { of other persons }\end{array}$} & $\begin{array}{l}\text { A mentor introduces student to pupils. } \\
\text { A mentor helps, when a student faces difficulties. }\end{array}$ & 2 \\
\hline
\end{tabular}


and to observation of other persons (teachers, mentors and pupils) emotions and their behaviour.

At the beginning of the Final practice the respondents feel themselves more comfortable when at the beginning of the Ist practice, because they already know pupils and mentors. On the first practice day the students have selected one or several pupils and started to work with them - talk to children, identify their problems, discuss the plans of support.

Respondent $\mathrm{D}$ writes about her feelings: how she was nervous starting to work with a child. She contemplates how to work with a child more effectively. After long work with a child (3 months) she has noticed progress and she is happy that a child (her client) has attempted to change his behaviour (to attend school and do his homework) and have made progress, and the respondent could help a child developing his social skills.

Organization of social skills development lessons is the practice activity, which has made the greatest impression of the respondent E. She has noticed that pupils listen to her willingly and they are interested in the tasks, which she suggested to them. She has also mentioned about her negative emotional state because of time lack preparing for practice tasks.

Respondent $\mathrm{F}$ has noticed that she has succeeded working individually with a girl. A girl has willingly accepted students help and has communicated sincerely. The respondent describes her comments about her client (a girl), her reactions to questions, and reactions of others to a girl's progress.

The respondents express their satisfaction that during the practice they have been able to help pupils and mentors; that the practice was useful to them (to the respondents); that the respondents have the purpose to work as social pedagogues.

Analysis of practice self-assessment. Assessing the executed practice, the respondents evaluate their own activity and behaviour and activity / behaviour of others, evaluate the process of practical learning.

In the self-assessment of the Ist professional activity practice students describe their feelings, what positive and negative emotions they have felt during the practice; how they have managed to do tasks, discuss emotions and behaviour of others (Table 3).

Respondent A discusses the quality of her activity, i. e. what she has managed to do, and what not. She points out that she has applied theoretical knowledge, which she has gained during studies. She has tried to do the tasks as well as she could. She has read a lot of new information.

Respondent B has gained more practical knowledge, developed his communication skills, working with children. He has faced some problems, but the mentor has helped to solve it.

Respondent $\mathrm{C}$ has noticed that communication and cognition of pupils help a social pedagogue to wok more efficient. The experience, obtained during the practice, has encouraged the respondent to study profession of a social pedagogue harder.

The respondents' attitude to the profession of social pedagogue, his activity does not change; they hope to work as social pedagogues after graduation. Respondents point out that work of a social pedagogue is important, creative, it requires professional vocation. The respondents have evaluated their activity during the practice very well (Table 4 ).

Table 3

Categorization of self-assessment of the Ist professional activity practice (N)

\begin{tabular}{|c|c|c|c|}
\hline Categories & \begin{tabular}{c|c|} 
Sub- \\
categories
\end{tabular} & Statements & $\begin{array}{l}\text { Number of } \\
\text { statements }\end{array}$ \\
\hline \multirow[t]{2}{*}{$\begin{array}{l}\text { Assessment of own } \\
\text { activity, learning, } \\
\text { emotions }\end{array}$} & $\begin{array}{c}\text { Positive } \\
\text { assessment }\end{array}$ & $\begin{array}{l}\text { Respondents obtained more knowledge, developed their competence. } \\
\text { They took over mentors' experience. } \\
\text { They were actively interested in work of a social pedagogue. } \\
\text { They learnt to systematize and analyze information about work of } \\
\text { a social pedagogue in a school. } \\
\text { The respondent liked the animation activity the most, because "I could } \\
\text { feel myself in shoes of a pedagogue". } \\
\text { Notification that it is necessary to learn more about various forms of } \\
\text { activity in order to employ pupils. } \\
\text { Comment that students joined school staff quickly. } \\
\text { Comment that they done willingly practice tasks. }\end{array}$ & 10 \\
\hline & $\begin{array}{c}\text { Negative } \\
\text { assessment }\end{array}$ & $\begin{array}{l}\text { The respondent noticed that there are a lot of irresponsible and } \\
\text { undisciplined pupils in a school. }\end{array}$ & 1 \\
\hline $\begin{array}{l}\text { Assessment of } \\
\text { others' behaviour, } \\
\text { activity }\end{array}$ & $\begin{array}{c}\text { Positive } \\
\text { assessment }\end{array}$ & $\begin{array}{l}\text { Pupils welcomed students-trainees warmly. } \\
\text { Social pedagogues employed pupils applying active, creative activities. } \\
\text { Social pedagogues shared their experience with students willingly. }\end{array}$ & 3 \\
\hline
\end{tabular}

Self-reflection as a tool of professional identity formation of future pedagogues 
Categorization of self-assessment of the Final professional activity practice $(\mathrm{N})$

\begin{tabular}{|c|l|l|c|}
\hline Categories & Sub-categories & \multicolumn{1}{c|}{ Statements } & $\begin{array}{c}\text { Number of } \\
\text { statements }\end{array}$ \\
\hline \multirow{2}{*}{$\begin{array}{c}\text { Assessment } \\
\text { of own activity, } \\
\text { learning, } \\
\text { emotions }\end{array}$} & $\begin{array}{c}\text { Positive } \\
\text { assessment }\end{array}$ & $\begin{array}{l}\text { They evaluated their work very well. } \\
\text { They helped pupils. } \\
\text { They could see positive results of their work. } \\
\text { They were happy that pupils and mentors communicated with } \\
\text { them willingly and warmly. }\end{array}$ & 5 \\
\cline { 2 - 5 } $\begin{array}{c}\text { Assessment } \\
\text { of others' } \\
\text { behaviour, } \\
\text { activity }\end{array}$ & $\begin{array}{c}\text { Negative } \\
\text { assessment }\end{array}$ & $\begin{array}{l}\text { It was difficult to leave children. } \\
\text { Too short duration of practice, seeking to do practice tasks. }\end{array}$ & 2 \\
\cline { 2 - 5 } & Possessment & $\begin{array}{l}\text { Mentors welcomed students' wish to help and their activity } \\
\text { willingly. } \\
\text { Children welcomed students' wish to help willingly. } \\
\text { They expressed hope to be in contact with the students in future. }\end{array}$ & 6 \\
\hline
\end{tabular}

In the self-assessment of the final professional activity practice students describe more widely their emotions and emotions of others, discuss activity, evaluate if. The respondents share their emotions with others, are more open. They feel stronger will to work as social pedagogues, and they get attached to children.

Respondent D has understood that she likes to work with children. She has felt very well when she has noticed kindliness and reliance of children; they hope to meet in the future. She has stressed that she likes profession of a social pedagogue very much.

Respondents $\mathrm{E}$ and $\mathrm{F}$ write what it has been both hard and easy for them to describe their emotional state at the end of the practice: they have been happy that their clients have changed and made progress. But they have felt sadness when the practice came to end.

\section{Conclusions}

1. Self-reflection can be defined as contemplation and evaluation of one's activity. That is analysing and contemplating of one's positive and negative emotions, behaviour, critical analysis of one's attitudes.
2. Application of self-reflection method helps a pedagogue to know himself better, notice positive and negative sides of his activity, reach his life goals. Self-reflection helps to develop in professional field. Self-reflection and writing of a diary helps future pedagogues to express themselves, understand better themselves and others. Writing of a diary raises practical learning into higher level.

3. Summarising the results of the empirical research it is possible to conclude that the respondents are not tended to write frankly about their emotions and contemplations. They concentrate more on description of activity. The respondents write a diary as persons, who do not yet know their abilities, are not self-confident. But it is possible to notice great change in the diaries of the respondents, recording the events of the Final practice after two years of studies. The respondents do not hide their feelings, describe their contemplations frankly, discuss behaviour and activity of themselves and others. And self-reflection of the Final practice is wider: the respondents discuss about efficiency of their activity, future plans and evaluate their abilities.

\section{References}

1. Bagdonas A. (2007). Socialinis darbas: profesinès veiklos ịvadas. Vilnius : VU Specialiosios pedagogikos labaratorija.

2. Bubnys R. (2010). Veiklos reflektavimo ir mokymosi teorinèse studijose iniversitete integralumas. Pedagogika, No. 99. Pp. 38-44.

3. Core Outcomes: Self-Reflection. (2013). 2000-2013 Portland Community College. Online reference: http://www.pcc.edu/edserv/core-outcomes/co-selfreflection.html

4. Geleziniene R. (2010). Reflektyvios mokytojo veiklos raiška specialiųjų ugdymosi poreikių turinčių mokinių mokymo(si) procese. Mokslas ir edukaciniai procesai. No. 4(13). Pp. 22-27.

5. Fidelindo L., \& Timothy Sh. (2013). Florence Nightingale: A pioneer of self-reflection. Nursing. Vol. 43. Issue 5. Pp. 1-3. Online reference: http://journals.lww.com/nursing/Fulltext/2013/05000/Florence Nightingale_A_pioneer_of_self_reflection.1.aspx.

6. Jovaisa L. (2007). Enciklopedinis žodynas. Vilnius : Gimtasis žodis. 
7. Ivanauskiene V., \& Liobikiene, N. (2010). Socialinio darbo studentų savirefleksijos gebėjimų ugdymas teoriniuose kursuose. Socialinis darbas. Mokslo darbai. No. 4(1). Pp. 118-121.

8. Leliugiene I. (2003). Socialinè pedagogika. Kaunas : Technologija.

9. Kam-Shin Y. (2005). Self-reflection in Reflective Practice: A Note of Caution. Oxford : Oxford University Press. Online reference: http://www.healthylifestylesliving.com/liberate-the-mind/self-help/the-power-of-self-reflection

10. Kavaliauskiene V. (2010). Refleksijos kultūra - socialinio darbuotojo profesinès veiklos raiškos aspektas. Acta Peadogogica Vilnensia. No. 25. Pp. 159-171.

11. Kvieskienė G. (2002). Socialinio pedagogo ABC. Vilnius.

12. Levesque R.J.R. (2012). Self-reflection. Essay of prof. Roder J.R. Levesque. Online reference: http://www.springerreference.com/docs/html/chapterdbid/329823.html

13. Lew M.D.N., \& Schmidt H.G. (2011). Self-reflection and academic performance: is there a relationship? Advances in Health Sciences Education: Theory and Practice. 2011 October; No. 16(4). Pp. 529-545. Published online 2011 May 5. doi: 10.1007/s10459-011-9298-z

14. Lukošūnienė V. (2011). Refleksija kaip integrali mokymosi mokytis kompetencijos dalis. Pedagogika. No. 101. Pp. 43-49.

15. Self-Reflection and Shared Reflection as Professional Tools. (2013). Online Reference: http://www.ehsnrc.org/ PDFfiles/selfreflection_sharedreflection.pdf

16. Swindell M.L., \& Watson J. (2013). Teaching Ethics through Self-Reflective Journaling. Journal of Social Work Values and Ethics. Vol. 3, No. 2. Oneline reference: http://www.socialworker.com/jswve/content/view/37/46

17. Tarptautinių žodžių žodynas. (2003). Vilnius.

18. Vinčaite E. (2013). Savirefleksijos metodo taikymas socialinio pedagogo profesinejje veikloje. The final theses. Kèdainiai : Kaunas College, Kèdainiai Jonušas Radvila Faculty.

19. Description of Teacher's Profession Competiences. (2007). Vilnius: LRS. Online Reference: https://e-seimas.lrs.lt/portal/legalAct/lt/TAD/TAIS.291726

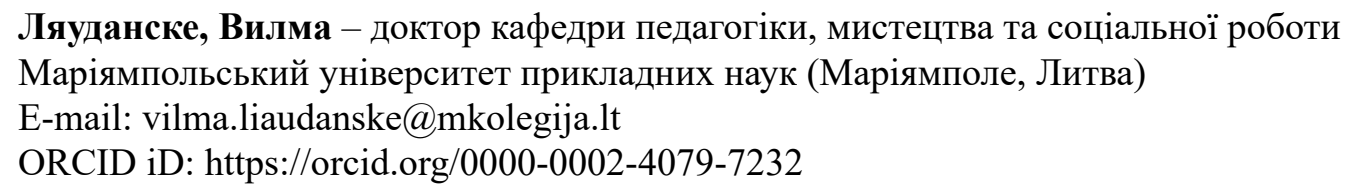

\title{
САМОРЕФЛЕКСІЯ ЯК ІНСТРУМЕНТ ФОРМУВАННЯ ПРОФЕСІЙНОЇ ІДЕНТИЧНОСТІ МАЙБУТНІХ ПЕДАГОГІВ
}

\begin{abstract}
Анотація
Метод саморефлексії - важливий чинник у практичній діяльності педагога, який прагне підвищити ефективність своєї роботи, зміцнити взаємозв'язок ідеального та реального явищ. Саморефлексія також допомагає відчувати задоволення від роботи. Саморефлексія сприяє співпраці педагога із клієнтом чи колегами. Лелюген трактує саморефлексію як об'єктивний аналіз професійної соціально-педагогічної діяльності. Вона стверджує, що джерелом рефлексії $є$ відносини з людиною, яка повинна створити для дитини таке середовище, в якому вона зможе зрозуміти свій психологічний стан, психологічні стани інших та сформувати свою рефлексивну функцію. Лукошюніє не виявила, що рефлексія корисна для навчання, роботи та особистого життя фахівців. Основна проблема - педагог повинен постійно аналізувати та оцінювати свою професійну діяльність та прагнути до іiі вдосконалення. Педагог, застосовуючи різні методи, може оцінювати свою діяльність, а саморефлексія - один із таких методів. Таким чином, автор статті намагається відповісти на проблемне питання - як майбутні педагоги застосовують метод саморефлексії у процесі практичного навчання. Об’єкт дослідження: саморефлексія, що формує професійну ідентичність майбутніх педагогів. Мета - проаналізувати аспекти застосування саморефлексії у процесі практичного навчання (як одного з етапів формування професійної ідентичності) майбутніх педагогів. Методи дослідження: аналіз наукової літератури та документів, аналіз щоденників практичних занять студентів та їх саморефлексії практик, контент-аналіз. Стаття складається із трьох частин. У першій частині автор обговорює важливість саморефлексії у діяльності педагогів. У другій частині представлено роль застосування саморефлексії у процесі роботи майбутніх педагогів, основні результати емпіричного дослідження представлені у третій частині статті.
\end{abstract}

Ключові слова: саморефлексія, професійна ідентичність, соціальна педагогіка, соціальний педагог, практичне навчання 
Ляуданске, Вильма - доктор кафедры педагогики, искуств и социальной работы Мариямпольский университет прикладных наук (Мариямполе, Литва)

E-mail: vilma.liaudanske@mkolegija.lt

ORCID iD: https://orcid.org/0000-0002-4079-7232

\section{САМОРЕФЛЕКСИЯ КАК ИНСТРУМЕНТ ФОРМИРОВАНИЯ ПРОФЕССИОНАЛЬНОЙ ИДЕНТИЧНОСТИ БУДУЩИХ ПЕДАГОГОВ}

Метод саморефлексии - важный фактор в практической деятельности педагога, стремящегося повысить эффективность своей работы, укрепить взаимосвязь идеального и реального явлений. Саморефлексия также помогает чувствовать удовлетворение от работы. Саморефлексия способствует сотрудничеству педагога с клиентом или коллегами. Лелюгене трактует саморефлексию как объективный анализ профессиональной социальнопедагогической деятельности. Она утверждает, что источником рефлексии являются отношения с человеком, который должен создать для ребенка такую среду, в которой он сможет понять свое психологическое состояние, психологические состояния других и сформировать свою рефлексивную функцию. Лукошюниене обнаружила, что рефлексия полезна для учебы, работы и личной жизни специалистов. Основная проблема - педагог должен постоянно анализировать и оценивать свою профессиональную деятельность и стремиться к ее совершенствованию. Педагог, применяя различные методы, может оценивать свою деятельность, а саморефлексия - один из таких методов. Таким образом, автор статьи пытается ответить на проблемный вопрос - как будущие педагоги применяют метод саморефлексии в процессе практического обучения. Объект исследования: саморефлексия, формирующая профессиональную идентичность будущих педагогов. Цель - проанализировать аспекты применения саморефлексии в процессе практического обучения (как одного из этапов формирования профессиональной идентичности) будущих педагогов. Методы исследования: анализ научной литературы и документов, анализ дневников практических занятий студентов и их саморефлексии практик, контент-анализ. Статья состоит из трех частей. В первой части автор обсуждает важность саморефлексии в деятельности педагогов. Во второй части представлена роль применения саморефлексии в процессе работы будущих педагогов. Основные результаты эмпирического исследования представлены в третьей части статьи.

Ключевые слова: саморефлексия, профессиональная идентичность, социальная педагогика, социальный педагог, практическое обучение

(C) The Author(s) 2021

Received date 30.09.2021

This is an open access article under

Accepted date 16.10.2021

the Creative Commons CC BY license

Published date 16.11.2021

How to cite: Liaudanske, Vilma. Self-reflection as a tool of professional identity formation of future pedagogues. HUMANITIES STUDIES : Collection of Scientific Papers / Ed. V. Voronkova. Zaporozhzhia : Publishing house "Helvetica", 2021. 9(86). P. 91-100.

doi: https://doi.org/10.26661/hst-2021-9-86-10 